\title{
OCORRÊNCIA DE ANTRACNOSE CAUSADA POR Colletotrichum acutatum EM PEQUIZEIRO NO DISTRITO FEDERAL*
}

\author{
JOSÉ R.N. ANJOS ${ }^{1}$, MARIA J.A. CHARCHAR ${ }^{1}$ \& ARTHUR K. AKIMOTO ${ }^{2}$ \\ ${ }^{1}$ Centro de Pesquisa Agropecuária dos Cerrados, Empresa Brasileira de Pesquisa Agropecuária, Cx. Postal 08223, \\ CEP 73301-970, Planaltina-DF, e-mail: ribamar@cpac.embrapa.br; ${ }^{2}$ Fundação de Apoio à Pesquisa Agropecuária e \\ Ambiental, Rodovia BR 262, Km 4, CEP 79002-970, Campo Grande-MS
}

(Aceito para publicação em 26/07/2001)

Autor para correspondência: José Ribamar N. Anjos

ANJOS, J.R.N., CHARCHAR, M.J.A. \& AKIMOTO, A.K. Ocorrência de antracnose causada por Colletotrichum acutatum em pequizeiro no Distrito Federal. Fitopatologia Brasileira 27:096-098. 2002.

\begin{abstract}
RESUMO
Colletotrichum acutatum foi consistentemente isolado de plantas de pequizeiro (Caryocar brasiliense) com sintomas de antracnose nas folhas, no Distrito Federal, em 2000. Testes de patogenicidade em casa de vegetação e o subsequente reisolamento do fungo confirmaram a hipótese de que $C$. acutatum é o agente etiológico da antracnose do pequizeiro. Os sintomas apareceram

quatro dias após a inoculação nas 20 plantas inoculadas. Dezoito espécies vegetais testadas foram suscetíveis ao fungo. A antracnose do pequizeiro causada por C. acutatum é relatada pela primeira vez no Brasil

Palavras-chave adicionais: Caryocar brasiliense, Cariocaraceae, patogenicidade.

\section{ABSTRACT \\ Occurrence of anthracnose caused by Colletotrichum acutatum on pequi in Federal District, Brazil}

The fungus Colletotrichum acutatum was consistently isolated from infected pequi (Caryocar brasiliense) plants with anthracnose symptoms in Federal District, Brazil, in 2000. Pathogenicity tests under greenhouse conditions and subsequent reisolations of $C$. acutatum from artificially inoculated pequi

seedlings confirmed the hypothesis that this fungus was the causal agent of the disease. Symptoms of anthracnose appeared four days after inoculation in 20 inoculated pequi plants. All 18 species of plants evaluated were susceptible to this fungus. Anthracnose of pequi caused by C. acutatum is reported for the first time in Brazil.
\end{abstract}

O pequizeiro (Caryocar brasiliense Camb.), família Caryocaraceae, é uma frutífera nativa amplamente disseminada no Brasil Central (Araújo, 1995; Naves, 1999). Sua madeira presta-se para construções rurais e fabricação de móveis (Almeida et al., 1998). Os frutos são comestíveis e servem para extração de óleo utilizado no preparo de pratos típicos da culinária regional, além de serem consumidos por várias espécies da fauna do cerrado. A polpa é usada, também, como medicinal e na indústria cosmética para fabricação de cremes. Quatro doenças já foram relatadas em pequizeiro (Silva et al., 1994): a podridão de raízes, causada por Cylindrocladium clavatum Hodges \& May, o mal-do-cipó, causado por Phomopsis sp., a morte descendente dos ramos, causada por Lasiodiplodia theobromae (Pat.) Griffone \& Maubl. e a podridão dos frutos, causada por L. theobromae (Pat.) Griffone \& Maubl. e por Phomopsis sp.

O objetivo desse trabalho foi identificar o agente etiológico da antracnose do pequizeiro constatada em condições naturais no Distrito Federal, avaliar sua patogenicidade em plântulas e frutos de pequizeiro e a gama parcial de hospedeiras.

\footnotetext{
*Apoio financeiro: Fundação de Apoio à Pesquisa do Distrito Federal (FAP$\mathrm{DF})$.
}

Em janeiro de 2000, foram observadas lesões foliares em plantas de pequizeiro, em um experimento sobre adaptação de fruteiras nativas no Cerrado, no campo experimental da Embrapa Cerrados, Planaltina, Distrito Federal. Os sintomas consistiam de grande quantidade de lesões irregulares de coloração marrom-escura nos folíolos, (Figura 1A). O isolamento do agente etiológico foi efetuado a partir de folhas lesionadas, em BDA + estreptomicina. Culturas monospóricas de Colletotrichum sp. provenientes desse isolamento foram remetidas para o CABI Bioscience, em Egham, Surrey, Reino Unido, onde foi identificado pelo Dr. P.F. Cannon como Colletotrichum acutatum J.H Simmonds (IMI 384185). As colônias do fungo eram inicialmente brancas, tornandose acinzentadas a partir do centro após cinco a seis dias de incubação a $25+1{ }^{\circ} \mathrm{C}$ e fotoperíodo de $12 \mathrm{~h}$. $\mathrm{O}$ verso era de coloração rósea com difusões irregulares escuras. Os conídios eram hialinos, asseptados, eretos e predominantemente fusiformes. Foram medidos 130 conídios em uma lâmina semi-permanente fixada com azul de tripano/lactofenol. As dimensões variaram de 7,75-20,0 x 2,5-5,0 $\mu \mathrm{m}$. Entretanto, a variação do comprimento de $95,4 \%$ dos conídios foi de 7,75 a $17,5 \mu \mathrm{m}$.

Para confirmar a patogenicidade desse isolado, mudas 


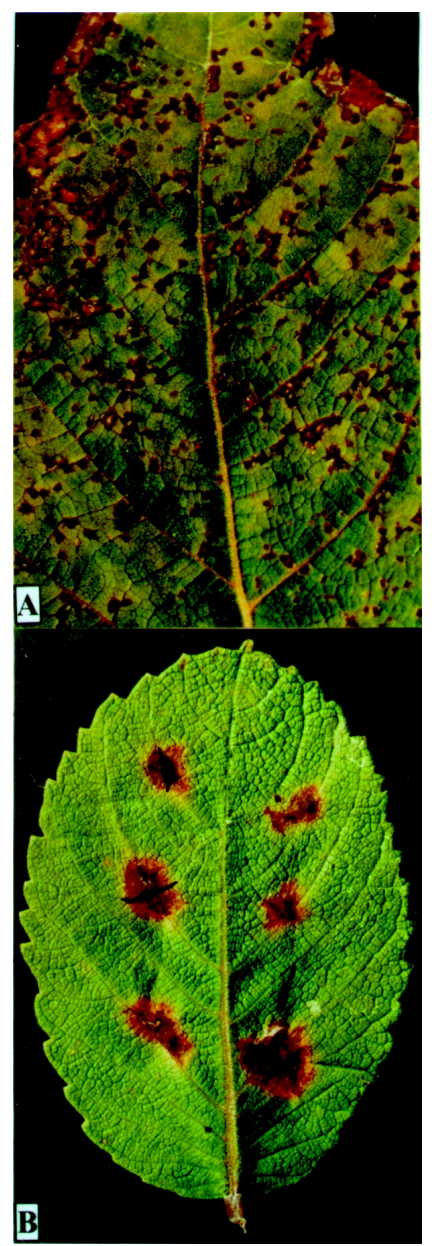

FIG. 1 - Sintomas de antracnose em folhas de pequizeiro (Caryocar brasiliense) induzidos por Colletotrichum acutatum. A) Sintomas em condições de campo. B) Sintomas após inoculação artificial com $C$. acutatum pelo método da aderência de disco de BDA com o fungo, após ferimento das folhas.

de pequizeiro com três meses de idade foram inoculadas usando-se três métodos: i) micélio e esporos de uma cultura monospórica multiplicada em BDA durante sete dias foram macerados em água destilada e estéril, ajustada à concentração de $1 \times 10^{6}$ esporos $/ \mathrm{ml}$ e pulverizados com atomizador manual em folhas de 20 mudas de pequizeiro previamente feridas com agulha esterilizada; ii) aderindo-se um disco de $5 \mathrm{~mm}$ de diâmetro da cultura do fungo em BDA após ferimento das folhas de 20 mudas de pequizeiro com agulha esterilizada; iii) uma suspensão de $1 \times 10^{6}$ esporos $/ \mathrm{ml}$ de água estéril foi pulverizada com atomizador manual nas folhas de 20 mudas de pequizeiro, sem ferimento. Para manter a umidade após a inoculação, as mudas foram cobertas com sacos plásticos e mantidas em bandejas com água dentro de uma câmara de incubação a $25^{\circ} \mathrm{C}$, durante $96 \mathrm{~h}$. Vinte mudas sadias, submetidas às mesmas condições, exceto que não foram tratadas com o fungo, serviram como testemunhas. Em seguida, as mudas foram transferidas para uma casa de vegetação. Os primeiros sintomas de antracnose (Figura 1B) foram observados em todas as plantas inoculadas pelos métodos acima, quatro dias após a inoculação. As plantas testemunhas permaneceram assintomáticas. O reisolamento de C. acutatum comprovou os postulados de Koch, confirmando-se assim a hipótese de que esse fungo é o agente causal da antracnose do pequizeiro.

A patogenicidade de C. acutatum foi avaliada também em frutos com idade aproximada de dois meses, os quais foram tratados superficialmente com hipoclorito de sódio a $1 \%$, cujo excesso foi removido com água estéril. Depois de ferir com agulha esterilizada, os frutos foram pulverizados com uma suspensão de $1 \times 10^{6}$ esporos $/ \mathrm{ml}$. Em seguida, foram cobertos com saco plástico e mantidos em condições de alta umidade em uma câmara incubadora a $25^{\circ} \mathrm{C}$, durante $72 \mathrm{~h}$. Vinte frutos sadios, submetidos às mesmas condições, exceto que não foram submetidos à pulverização com suspensão de C. acutatum, serviram como testemunhas. Foram observadas lesões escuras e profundas em todos os frutos inoculados. O reisolamento de C. acutatum comprovou a patogenicidade desse fungo também em frutos de pequizeiro.

Utilizando-se do segundo método de inoculação, 18 espécies, das quais dez nativas, pertencentes a 14 famílias botânicas foram inoculadas com o isolado de C. acutatum em estudo. Todas as espécies testadas mostraram sintomas de antracnose (Tabela 1). A descoberta desse patógeno causando antracnose em pequizeiro, acrescenta nova hospedeira natural às diversas já relatadas anteriormente (Hopkins et al., 1985; Smith et al., 1986; Freeman et al., 1993).

TABELA 1 - Reação de espécies vegetais à infecção quando inoculadas com Colletotrichum acutatum isolado de pequizeiro (Caryocar brasiliense)

\begin{tabular}{|c|c|c|c|}
\hline Espécie & Família & Nome Comum & $\begin{array}{l}\text { P. inoc./ } \\
P \text {.sint. }\end{array}$ \\
\hline Anacardium humile Mart. & Anacardiaceae & caju-do-campo & $10 / 10$ \\
\hline Coffea arabica L. 'Acaiá Cerrado' & Rubiaceae & café & $10 / 10$ \\
\hline Dipteryx alata Vog. & $\begin{array}{c}\text { Leguminosae } \\
\text { (Papilionoideae) }\end{array}$ & baru & $10 / 10$ \\
\hline Eugenia dysenterica Mart. ex DC. & Myrtaceae & cagaita & $10 / 10$ \\
\hline Glycine $\max$ L. (Merr.) 'Carla' & Leguminosae & soja & $10 / 7$ \\
\hline Gossypium hirsutum L. 'Deltapine' & , Malvaceae & algodão & $10 / 8$ \\
\hline Grevillae robusta A. Cunn. & Proteaceae & grevillae & $10 / 10$ \\
\hline Hancornia speciosa Gomez & Apocynaceae & mangaba & $10 / 8$ \\
\hline Helianthus annuus L. & Asteraceae & girassol & $10 / 8$ \\
\hline Hymenaea stigonocarpa Mart. & Leguminosae & jatobá & $10 / 10$ \\
\hline Joannesia princeps Vell. & Euphorbiaceae & cutiera & $10 / 10$ \\
\hline Lycopersicon esculentum Mill. & Solanaceae & tomate & $10 / 10$ \\
\hline Mangiferae indica L. 'T. Atkins' & Anacardiaceae & manga & $10 / 10$ \\
\hline Myracrodruon urundeuva & Anacardiaceae & aroeira & $10 / 10$ \\
\hline Passiflora edulis f. flavicarpa ' $E$ ' & Passifloraceae & maracujá-azedo & $10 / 10$ \\
\hline Simarouba versicolor St. Hil. & Simaroubaceae & mata-cachorro & $20 / 20$ \\
\hline Toona ciliata & Meliaceae & toona & $10 / 10$ \\
\hline Caryca papaya & Carycaceae & mamão & $10 / 6$ \\
\hline
\end{tabular}


J.R.N. Anjos et al.

\section{REFERÊNCIAS BIBLIOGRÁFICAS}

ALMEIDA, S.P., PROENÇA, C.E.B., SANO, S.M. \& RIBEIRO, J.F. Cerrado-espécies vegetais úteis. Planaltina: EMBRAPACPAC. 1998.

ARAÚJO, F.D. A review of Caryocar brasiliense (Caryocaraceae)an economically valuable species of the Central Brazilian Cerrados. Economic Botany 49:40-48. 1995.

FREEMAN, S., PHAM, M. \& RODRIGUEZ, R.J. Molecular Genotyping of Colletotrichum Species Based on Arbitrary Primed PCR, A + T- Rich, and Nuclear DNA Analyses. Experimental Mycology 17:309-322. 1993.

HOPKINS, J.C., LOCK, W. \& FUNK, A. Colletotrichum acutatum, a new pathogen on western hemlock seedlings in British Columbia. Canadian Plant Disease Survey 65:1113. 1985.

NAVES, R.V. Espécies frutíferas nativas dos cerrados de Goiás: caracterização e influências do clima e dos solos. (Dissertação Doutorado) Goiânia, Escola de Agronomia, Universidade Federal de Goiás. 1999.

SILVA, J.A., SILVA, D.B., JUNQUEIRA, N.T.V. \& ANDRADE, L.R.M. Frutas nativas dos cerrados. Brasília: EMBRAPACPAC, 1994.
SMITH, B.J., POPLARVILLE, M.S. \& BLACK, L.L. First Report of Coletotrichum acutatum on Strawberries in the United States. Plant Disease 70:1074. 1986.

A review of Caryocar brasiliense (Caryocaraceae)-an economically valuable species of the Central Brazilian Cerrados. Economic Botany 49:40-48. 1995.

FREEMAN, S., PHAM, M. \& RODRIGUEZ, R.J. Molecular Genotyping of Colletotrichum Species Based on Arbitrary Primed PCR, A + T- Rich, and Nuclear DNA Analyses. Experimental Mycology 17:309-322. 1993.

HOPKINS, J.C., LOCK, W. \& FUNK, A. Colletotrichum acutatum, a new pathogen on western hemlock seedlings in British Columbia. Canadian Plant Disease Survey 65:11-13. 1985.

NAVES, R.V. Espécies frutíferas nativas dos cerrados de Goiás: caracterização e influências do clima e dos solos. (Dissertação Doutorado) Goiânia, Escola de Agronomia, Universidade Federal de Goiás. 1999.

SILVA, J.A., SILVA, D.B., JUNQUEIRA, N.T.V. \& ANDRADE, L.R.M. Frutas nativas dos cerrados. Brasília: EMBRAPACPAC, 1994.

SMITH, B.J., POPLARVILLE, M.S. \& BLACK, L.L. First Report of Coletotrichum acutatum on Strawberries in the United States. Plant Disease 70:1074. 1986. 